\title{
Mortality experience of workers exposed to vinyl chloride monomer in the manufacture of polyvinyl chloride in Great Britain
}

\author{
A. J. FOX* AND P. F. COLLIER \\ Office of Population Censuses and Surveys, St Catherines House, 10 Kingsway, London WC2B 6JP and \\ Health and Safety Executive, Employment Medical Advisory Service (EMAS)
}

ABSTRACT Identification particulars were obtained for over 7000 men who were at some time between 1940 and 1974 exposed to vinyl chloride monomer in the manufacture of polyvinyl chloride. Approximately $99 \%$ of these men have been traced and their mortality experience studied. The overall standardised mortality ratio, 75.4 , shows a significant reduction compared with the national rates. Four cases of liver cancer were found. Two of these have been confirmed by a panel of liver pathologists as angiosarcoma and two as not angiosarcoma. There is no evidence to support the hypothesis that cancers other than those of the liver are associated with exposure to vinyl chloride monomer. The two cases of angiosarcoma were found in men who had been exposed to high concentrations of the monomer although the second man died only eight years after first exposure. The industry in Great Britain has expanded considerably since the second world war with over $50 \%$ of men having entered within the last decade. Conclusions drawn about the effect of vinyl chloride monomer on the mortality experience of men in this industry must consequently be tempered by the reservation that the full impact may not yet be in evidence.

In 1974 three cases of angiosarcoma of the liver in workers at a plant manufacturing polyvinyl chloride (PVC) in the United States of America were reported (Creech and Johnson, 1974). Further investigation by the firm led to the identification of two further cases who had died some years previously (Block, 1974). A programme of medical surveillance at the plant (Makk et al., 1974) resulted in the identification of two cases of angiosarcoma of the liver among current workers (Falk et al., 1974).

The rarity of this tumour may be judged from the incidence of reported cases: for the USA 20 to 25 cases a year (British Medical Journal, 1974) and for England and Wales some three to four cases a year (Baxter and Fox, 1975). Previously the only agents reported as associated with the development of angiosarcoma of the liver were arsenic (Regelson et al., 1968) and thorotrast (MacMahon et al., 1947).

The first case of angiosarcoma of the liver in a man known to have been exposed to vinyl chloride monomer (VCM) in the manufacture of PVC in

*Formerly with EMAS

Received for publication 19 April 1976

Accepted for publication 16 June 1976
Great Britain was reported by Lee and Harry (1974). The man had been a process worker for 20 years and he died in 1972 aged 71 years. At this time 19 cases of angiosarcoma in workers who had been exposed to VCM in the manufacture of PVC had been reported throughout the world. All these men had been exposed to extremely high concentrations of VCM usually as autoclave 'pot' cleaners. By 1975 some 32 cases had been reported all of which were in men who had been associated with the manufacture of PVC (Lloyd, 1975). These included a second British patient who had been exposed for four years and died aged 37 years only eight years after first exposure.

Early reports of epidemiological studies in the USA have been given by Monson et al. (1974), Tabershaw and Gaffrey (1974), Falk et al. (1974), Makk et al. (1974), and Nicholson et al. (1975). The Employment Medical Advisory Service (EMAS), with the assistance of company medical representatives and the support of the unions, co-ordinated a prospective mortality study covering the manufacturing industry in Great Britain. The objectives of this study were to present a general picture of the mortality experience of workers engaged in the in- 
dustry in Great Britain and to relate this to factors such as sex, age, year of entry into the industry, length of time exposed, and exposure levels.

\section{Methods}

The study covers all workers who may have been exposed to VCM through having been employed in this industry in Great Britain. All new entrants are being added to the population annually. Only four companies manufacture PVC and they have kept most of their personnel records at least since these processes were introduced. The companies were asked to supply EMAS with the names, sex, address (date at which pertinent), date of birth, year of entry into the industry, year of departure, job resulting in highest exposure, and maximum level of exposure for each person who had entered their employment.

As full job histories were not readily available for the population as a whole, it was decided to record the activity in which the maximum exposure was likely to have occurred and to follow-up individual cases, such as those dying with the mention of liver disease on their death certificate, to obtain a more complete job history. No measurement of the levels of exposure experienced by people employed before the mid-1960s was available. Estimates were made by the companies using the definitions:

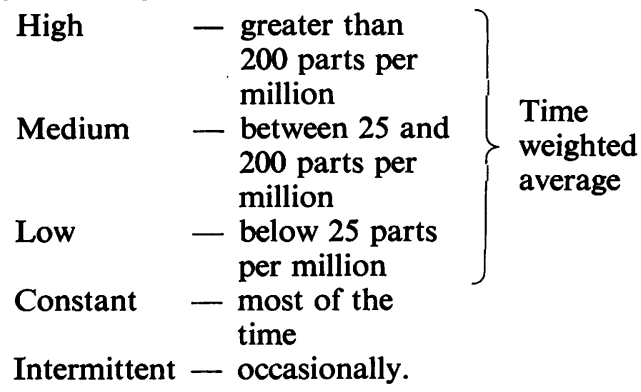

All data provided by the companies were subsequently re-checked by them once they had been computerised. Throughout this analysis and discussion it is assumed that the information given to EMAS is accurate. It is also necessary to assume that persons not included in this analysis, either because they were not identified or because adequate data were not available, do not constitute a biased sample.

The number of deaths observed is compared with that expected using sex and age standardised death rates for England and Wales. Five-year age groups have been used for ages between 15 and 74 years. The Office of Population Censuses and Surveys (OPCS) provided death rates in accordance with the International Classification of Diseases (8th Revision) for the certified causes of interest and re-coded all death certificates for people in the study population who died before 1968 (the year the 8th Revision was introduced). Death rates calculated for 1951, 1961, and annually after 1966 were applied to the person-years-at-risk for 1940-55, 1956-65, and annually after 1966. As 1974 death rates were not available, 1973 death rates were applied to 1974 person-years-at-risk. A comparison between observed and expected values is made by assuming a Poisson distribution with mean equal to the expected value. Pearson and Hartley (1962) give the probabilities of individual terms of the Poisson distribution. For a mean greater than 15.0 the normal (gaussian) approximation to the Poisson distribution has been assumed.

\section{Results}

\section{THE POPULATION}

These results cover the period between 1940 and 1974. Information relating to the deaths in people who entered in 1975 is not included nor is the fact that some people left during 1975. This information was made available during 1975 and will therefore be added to future analyses. Complete information on 7717 workers was obtained from the companies participating in the study. This was forwarded to the OPCS who notified EMAS of those whom they had traced together with the findings. Table 1 shows that 85 workers, only $1.1 \%$ of the initial population, had not been traced at the time of analysis. This figure includes 59 workers at one factory for whom identifying information was scanty. Another 72 workers $(0.9 \%)$ who were traced were excluded because of inadequate information on their work history in the industry. A total of 409 deaths were recorded, 393 men and 16 women, and 148 workers emigrated before 1975. Two who emigrated returned during 1975 to live in Great Britain and will be included in future analyses. Male deaths have been studied in detail, but because so few women are involved in this industry their deaths are summarised in Appendix 1. Appendix 2 gives the deaths in 1940-74 notified since the analysis.

Figure 1 shows the number of men employed in the industry each year from 1940 onwards and the number who had been previously employed. The work force in 1974 represents some $53 \%$ of men ever employed in the industry, reflecting the rapid growth since its inception. Table 2 shows that approximately $12 \%$ of men were exposed to high levels, almost all to constant high levels. The newness of the industry is reflected by the fact that only $8 \%$ of the workers have been employed in the industry for more than 20 years. Of these, only 34 men had been exposed to constant high levels. 
Table 1 Summary of the number of persons identified, traced, and flagged by the Office of Population Censuses and Surveys according to factory

\begin{tabular}{|c|c|c|c|c|c|c|c|}
\hline \multirow{2}{*}{\multicolumn{2}{|c|}{$\begin{array}{l}\text { Factory (date of initial } \\
\text { production) } \ddagger\end{array}$}} & \multicolumn{2}{|c|}{ Number identified } & \multirow[t]{2}{*}{ Not traced } & \multirow{2}{*}{$\begin{array}{l}\text { Missing } \\
\text { information }\end{array}$} & \multirow{2}{*}{$\begin{array}{l}\text { Deaths* } \\
1940-74\end{array}$} & \multirow{2}{*}{$\begin{array}{l}\text { Emigrations } \\
1940-74\end{array}$} \\
\hline & & Men & Women & & & & \\
\hline \multicolumn{2}{|c|}{ Total population } & 7561 & 156 & $85(1 \cdot 1 \%)$ & $72(0.9 \%)$ & 409 & 148 \\
\hline
\end{tabular}

*Deaths in men and women.

tIncludes one person who died abroad who has been excluded from the study.

†First year in which more than 50 people were in current employment.

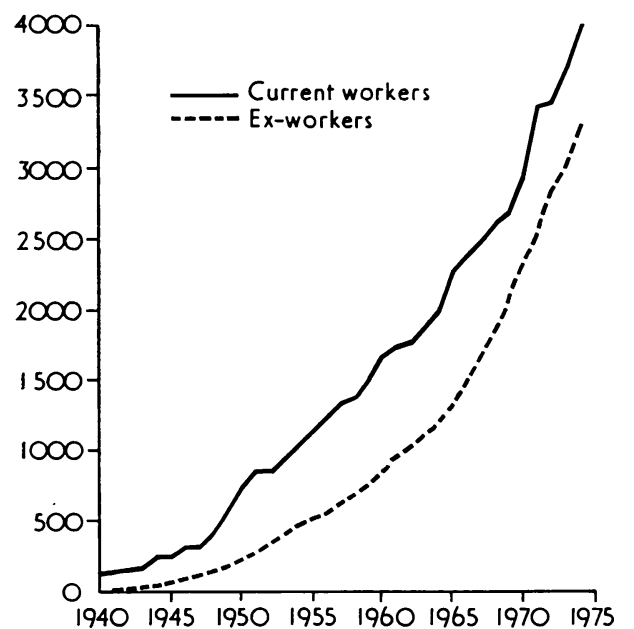

Fig. 1 Number of men in the industry and the total number who had left the industry for each year since 1940.
OVERALL MORTALITY PATTERN

Table 3 shows that only 393 deaths have been recorded as compared with $521 \cdot 22$ expected and the standardised mortality ratio (SMR) is $75 \cdot 4$. The SMR for cancers as a group is higher than this whereas the SMR for circulatory disease is approximately the same and that for respiratory disease, digestive disease, accidents, and suicides is below the overall SMR.

It is difficult to identify angiosarcoma of the liver from death certificates (Baxter and Fox, 1975). Some cases will be classified as primary liver cancers (ICD no. 155), some as secondary or unspecified liver cancer (ICD no. 197.7 or 197.8), and others may be in other categories (for example $I C D$ no. 227). Only one death was certified as being caused by primary liver cancer compared with $\mathbf{0 . 7 1}$ expected. There were however three deaths, nearly $2 \frac{1}{2}$ times the expected number, in these other categories. Histories for these four people are summarised in Table 4. Slides for microscopical analysis obtained from these cases were referred with no

Table 2 Levels of exposure and lengths of exposure for men included in the survey

\begin{tabular}{|c|c|c|c|c|c|c|c|}
\hline \multirow{3}{*}{$\begin{array}{l}\text { Length of exposure } \\
\text { (years) }\end{array}$} & \multicolumn{6}{|c|}{ Levels of exposure } & \multirow[t]{3}{*}{ Total no. (\%) } \\
\hline & \multicolumn{3}{|l|}{ Constant } & \multicolumn{3}{|l|}{ Intermittent } & \\
\hline & High & Medium & Low & High & Medium & Low & \\
\hline $\begin{array}{c}0-9 \\
10-19 \\
20+\end{array}$ & $\begin{array}{r}605 \\
142 \\
34\end{array}$ & $\begin{array}{r}1202 \\
117 \\
92\end{array}$ & $\begin{array}{l}890 \\
263 \\
114\end{array}$ & $\begin{array}{l}60 \\
35 \\
11\end{array}$ & $\begin{array}{r}1857 \\
210 \\
130\end{array}$ & $\begin{array}{r}1094 \\
351 \\
202\end{array}$ & $\begin{array}{c}5708(77.0 \%) \\
1118(15 \cdot 1 \%) \\
583(7.9 \%)\end{array}$ \\
\hline Total (\%) & $781(10 \cdot 5 \%)$ & $1412(19.0 \%)$ & $1266(17 \cdot 1 \%)$ & $106(1.4 \%)$ & $2197(29 \cdot 7 \%)$ & $1647(22 \cdot 2 \%)$ & $7409(100 \%)$ \\
\hline
\end{tabular}

Constant $=$ Most of the time.

Intermittent $=$ Occasionally.

High $=>200$ parts per million.

Medium $=200$ parts per million $\geqslant x \geqslant 25$ parts per million. $\}$ Time weighted average.

Low $\quad=<25$ parts per million. 
Table 3 Observed and expected deaths, for 1940 to 1974, for all men covered by the survey, according to certified cause of death

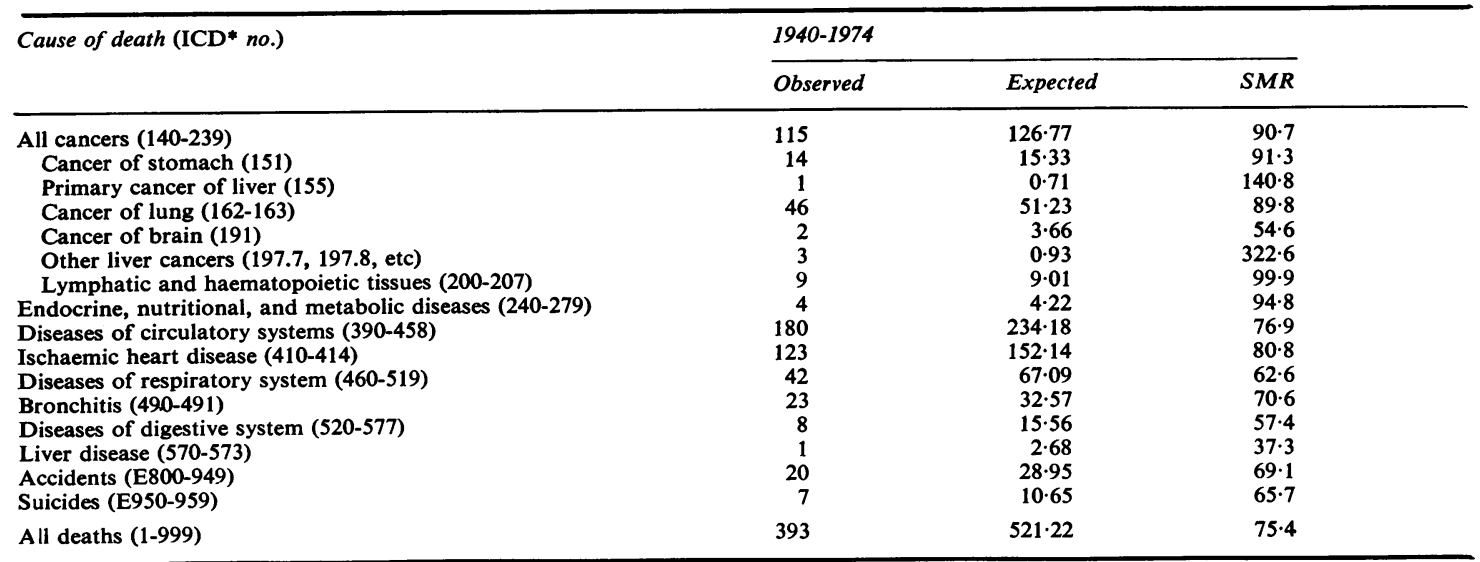

*All deaths have been coded according to the International Classification of Diseases, 8th Revision.

Table 4 Deaths due to liver cancer

\begin{tabular}{|c|c|c|c|c|c|c|c|}
\hline Factory no. & Date of birth & Date of death & Certified cause of death & $\begin{array}{l}\text { Year } \\
\text { joined }\end{array}$ & $\begin{array}{l}\text { Year } \\
\text { left }\end{array}$ & $\begin{array}{l}\text { Exposure } \\
\text { levels }\end{array}$ & $\begin{array}{l}\text { Job } \\
\text { description }\end{array}$ \\
\hline 2 & $27 / 10 / 1915$ & $10 / 2 / 1970$ & $\begin{array}{l}\text { Ascites; carcinoma of liver } \dagger \text { and } \\
\text { omentum }\end{array}$ & 1961 & 1967 & $\begin{array}{l}\text { Low/inter- } \\
\text { mittent }\end{array}$ & Fitter \\
\hline 2 & $20 / 4 / 1901$ & $23 / 12 / 1972$ & $\begin{array}{l}\text { Haemangioendothelioma of liver*; } \\
\text { verdict, natural causes }\end{array}$ & 1946 & 1966 & High/constant & $\begin{array}{l}\text { Autoclave } \\
\text { operator } \\
(1948-61)\end{array}$ \\
\hline 2 & $15 / 6 / 1913$ & $4 / 5 / 1973$ & $\begin{array}{l}\text { Undifferentiated carcinoma of livert, } \\
\text { primary }\end{array}$ & 1951 & 1969 & $\begin{array}{l}\text { Medium/inter- } \\
\text { mittent }\end{array}$ & $\begin{array}{l}\text { Process } \\
\text { operator }\end{array}$ \\
\hline 11 & $2 / 6 / 1937$ & $24 / 12 / 1974$ & $\begin{array}{l}\text { Carcinomatosis; angiosarcoma of } \\
\text { liver*; hepatic cirrhosis }\end{array}$ & 1966 & 1974 & High/constant & Polycleaner \\
\hline
\end{tabular}

*Confirmed by panel of histopathologists as due to angiosarcoma of liver.

+Confirmed by panel of histopathologists as not due to angiosarcoma of liver.

Table 5 Observed and expected deaths and standardised mortality ratio for all deaths between 1940 and 1974 according to factory

\begin{tabular}{lrrr}
\hline Factory no. & $\begin{array}{l}\text { Observed } \\
\text { deaths }\end{array}$ & $\begin{array}{l}\text { Expected } \\
\text { deaths }\end{array}$ & SMR \\
\hline 2 & 77 & $86 \cdot 67$ & $88 \cdot 8$ \\
3 & 13 & $55 \cdot 63$ & $23 \cdot 4$ \\
4 & 137 & $163 \cdot 17$ & $84 \cdot 0$ \\
5 & 4 & $5 \cdot 19$ & $77 \cdot 1$ \\
10 & 2 & $16 \cdot 29$ & $12 \cdot 3$ \\
11 & 153 & $176 \cdot 90$ & $86 \cdot 5$ \\
12 & 2 & $4 \cdot 35$ & $45 \cdot 0$ \\
13 & 5 & $13 \cdot 02$ & $38 \cdot 4$ \\
Total population & 393 & $521 \cdot 22$ & $75 \cdot 4$ \\
\hline
\end{tabular}

details of their work history to a panel of liver pathologists (Baxter, 1976). A diagnosis of primary angiosarcoma of the liver was confirmed in two of them and the remaining two were confirmed as not being due to angiosarcoma.
INDIVIDUAL FACTORY EXPERIENCE

Table 5 shows that significantly fewer deaths were observed for men employed in factories 3, 10, and 13 than would be expected from the numbers employed and their ages. In factory 10, 59 workers could not be traced and a further 36 were excluded from the analysis because of inadequate exposure information. Of these 36, three have died. The proportion of persons from this factory not traced is so much higher than for the other factories that it may include a disproportionately high number of deaths. Some early records for factory 3 were not accessible and these may also include a high proportion of deaths. The factories with the highest number of expected deaths (factories 2, 4, and 11) had similar SMRs. $(88 \cdot 8,84.0$, and 86.5 respectively). The low number of expected deaths for factory 13 relative to the number employed is a reflection of its expansion during recent years.

Three of the liver cancer deaths occurred in: 
factory 2 after 1966 (Table 4). This is significantly in excess of the expected $0.13(P<0.01)$. The number of deaths attributed to cancer, 21 observed, is marginally in excess of the expected $20 \cdot 71$, whereas the number from circulatory disease is below that expected (37 observed, 40.27 expected). Factory 4 shows a similar pattern with 41 observed cancers compared with $39 \cdot 26$ expected and 60 deaths attributed to circulatory disease compared with 73.58 expected, as does factory 11 with 44 observed cancers, 43.14 expected, and 71 circulatory disease deaths compared with 80.08 expected. While these differences are not statistically significant they indicate that in the three factories with the highest expected number of deaths, the SMR for cancer deaths was in excess of the SMR for all deaths and that for deaths associated with circulatory disease.

Little further information was gained by analysing deaths by certified cause separately for each factory. Therefore in the following analysis all data have been combined.

\section{MORTALITY BY YEAR ENTERING THE}

\section{INDUSTRY}

Table 6, by comparing cohorts who entered the industry in different quinquennia, shows that the ratio of observed to expected deaths is lower for those men who entered the industry recently. Figure 2 shows this to be the case for cancer and circulatory disease. The opposite trend is shown for accidents. Although the downward slope with succeeding year of entry is seen in Fig. 3 and Table 7 to be due to more recent cohorts having lower SMRs than earlier cohorts, the SMR for each cohort is seen to rise the longer the cohort is followed-up (Table 8). The SMRs increase from 40.5 for the first five years of follow-up, to 85.1 for between 15 and 20 years of follow-up, to 106.5 for 30 to 35 years of follow-up.

\section{MORTALITY BY EXPOSURE LEVEL}

The overall SMR in Table 9 is seen to be lowest in the group with the highest exposure, $67 \cdot 8$, and highest in the group with the lowest exposure, 78.0. The SMR for liver cancer was however highest in the group exposed to the highest concentration of
VCM. The two liver cancers in this group were both angiosarcomas whereas the liver cancers in the low and medium exposure groups were not (Table 4). The only other high SMR in Table 9 is for brain cancer in the high exposure group. This results from one case being observed whereas 0.36 were expected. There is no indication of a dose-response relationship for cancer as a group, lung cancer, or diseases of the circulatory system and only a slight indication for diseases of the respiratory system where the SMR is increased from 59.7 to 64.4 to 69.1 with successive rises in exposure group; and only a slight and probably meaningless increase for diseases of the respiratory system.

The SMR (Table 10) for those men who experienced constant exposures to VCM, 55.3, is signifcantly below that for men who experienced only intermittent exposures, 84.1. The SMR for liver cancer is however higher in the former group. The two angiosarcoma deaths were men who had experienced constant exposure (Table 4). This table indicates an excess of lung cancers in men constantly exposed (17 observed, 15.72 expected, $P>0.05$ ) which arises from men exposed constantly to medium concentrations (13 observed, 7.75 expected, $P>$ $0.05)$. This group also had a slightly raised bronchitis rate (6 observed, 4.56 expected, $P>0.05$ ).

In Table 11 cohorts based on men not in the industry but who were alive 15 years after entry are subdivided according to the length of time spent in the industry. Fifteen-year survivors are considered in order to eliminate the biases that occur in a simple comparison with length of exposure. These arise because a man exposed for 15 years cannot have died before he completed this exposure, whereas a man who was exposed for less than five years may have died within five years of entering the industry. The mortality experience of the four cohorts considered in Table 11, men who entered between 1940 and 1944, between 1945 and 1949, between 1950 and 1954, and between 1955 and 1959 have been studied for 16 years, 11 years, six years, and one year respectively. Although there is a slight drop in the SMR in relation to the length of exposure for the 1940-44 cohort, there is an overall tendency for the

Table 6 Analysis of observed and expected deaths by year of entry

\begin{tabular}{|c|c|c|c|c|c|c|c|}
\hline \multirow[t]{2}{*}{ All deaths } & \multicolumn{7}{|c|}{ Year of entry } \\
\hline & $1940-44$ & $1945-49$ & $1950-54$ & $1955-59$ & $1960-64$ & $1965-69$ & $1970-74$ \\
\hline $\begin{array}{l}\text { Observed } \\
\text { Expected } \\
\text { SMR }\end{array}$ & $\begin{array}{c}89 \\
101 \cdot 85 \\
87 \cdot 4\end{array}$ & $\begin{array}{c}103 \\
122 \cdot 87 \\
83 \cdot 8\end{array}$ & $\begin{array}{c}87 \\
125 \cdot 81 \\
69 \cdot 2\end{array}$ & $\begin{array}{l}53 \\
76 \cdot 64 \\
69 \cdot 2\end{array}$ & $\begin{array}{l}26 \\
40 \cdot 69 \\
63 \cdot 9\end{array}$ & $\begin{array}{l}19 \\
30 \cdot 84 \\
61 \cdot 6\end{array}$ & $\begin{array}{l}9 \\
16 \cdot 96 \\
53 \cdot 1\end{array}$ \\
\hline
\end{tabular}

Six deaths in men who entered before 1940 are not included in this table. 


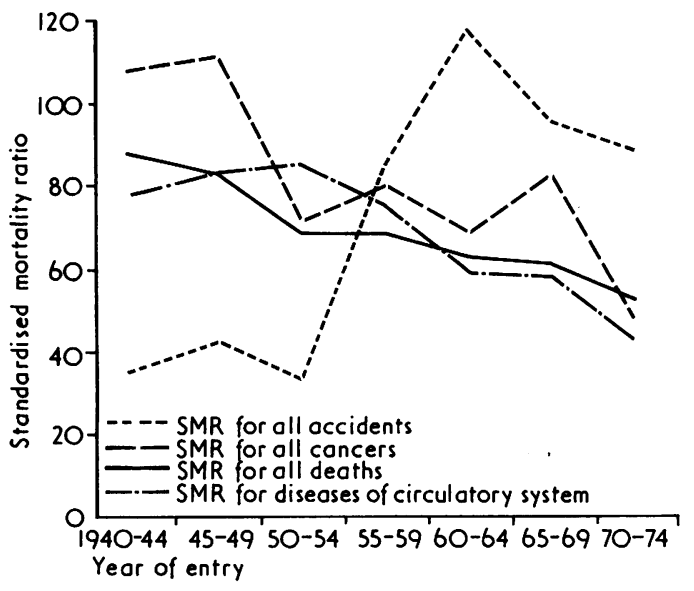

Fig. 2 Standardised mortality ratios for all deaths, all cancers, diseases of circulatory system, and accidents related to the year of entry into industry.

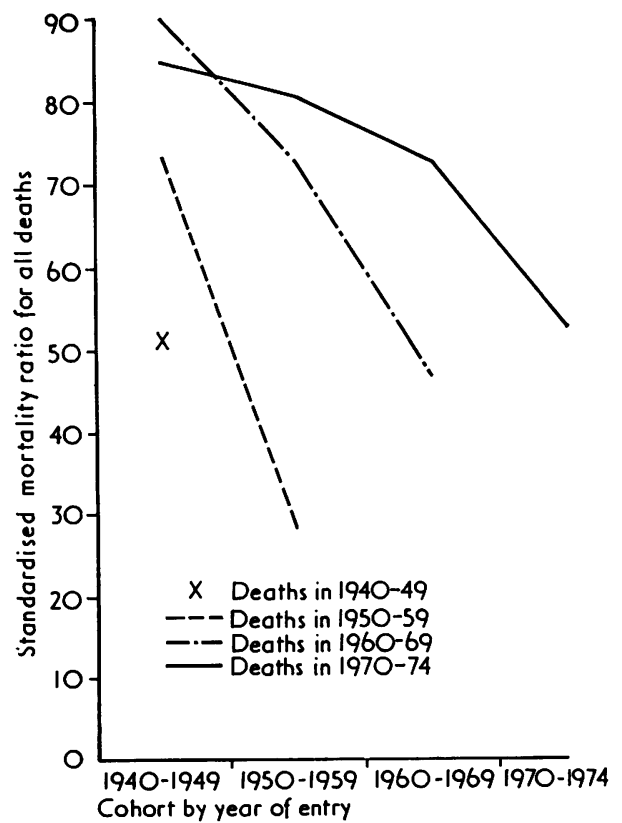

Fig. 3 Standardised mortality ratios for deaths from all causes according to year of death for cohorts based on year of entry into industry.

SMR to increase with increased exposure. The total SMR increases from 100.6 for those exposed for four years or less, to $104 \cdot 7$ for those exposed for five to nine years, to $113 \cdot 3$ for those exposed for 10 to 14 years.
Table 7 Observed and expected deaths from all causes and SMRs according to year of death for cohorts based on year of entry to the industry

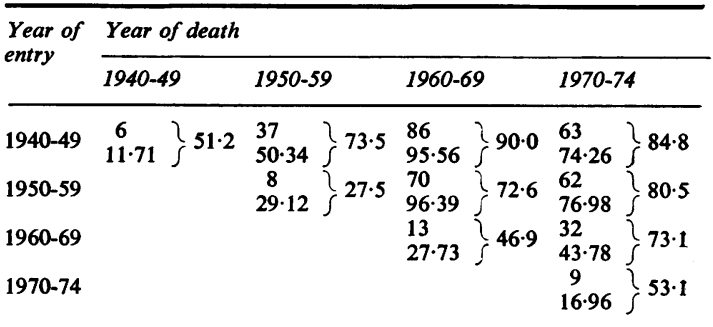

Six deaths in men who entered before 1940 are not included in this table.

Table 8 Observed and expected deaths in relation to length of time each cohort has been followed-up

\begin{tabular}{llcr}
\hline $\begin{array}{l}\text { Length of time } \\
\text { cohort followed-up } \\
\text { (years) }\end{array}$ & $\begin{array}{l}\text { Observed } \\
\text { deaths }\end{array}$ & $\begin{array}{l}\text { Expected } \\
\text { deaths }\end{array}$ & SMR \\
\hline $0-4$ & 20 & $49 \cdot 32$ & $40 \cdot 5$ \\
$5-9$ & 50 & $86 \cdot 44$ & $57 \cdot 8$ \\
$10-14$ & 65 & $93 \cdot 57$ & $69 \cdot 5$ \\
$15-19$ & 87 & $102 \cdot 22$ & $85 \cdot 1$ \\
$20-24$ & 80 & $92 \cdot 69$ & $86 \cdot 3$ \\
$25-29$ & 54 & $70 \cdot 41$ & 76.7 \\
$30-34$ & 30 & $28 \cdot 18$ & $106 \cdot 5$ \\
\hline
\end{tabular}

Six deaths in men who entered before 1940 are not included in this table.

\section{Discussion}

This industry has grown approximately tenfold since the second world war (Fig. 1). It is nearly twice as large as it was only 10 years ago. The environmental conditions in the manufacturing processes are also known to have altered since men were first employed in the industry in the early 1940s. The main factors affecting the exposure levels were firstly, in the mid-sixties the discovery that exposure to high concentrations of VCM can cause acro-osteolysis and Raynaud-like phenomena which have since been classified under the heading vinyl chloride disease; and secondly, in 1974 the discovery that men exposed to high concentrations of VCM had an increased risk of dying from angiosarcoma of the liver.

These changes in the size of industry and exposure mean that more than half of the people who have ever been exposed to VCM in the manufacture of PVC in Great Britain are currently employed in the industry; approximately $75 \%$ of men who have been employed in the industry have been employed for less than 10 years; only $8 \%$ have been employed for 20 years or longer; approximately half the persons. who have been exposed to VCM have been intermit- 
Table 9 Observed and expected deaths according to whether exposure was thought to be high, medium, or low

\begin{tabular}{|c|c|c|c|c|c|c|c|c|c|}
\hline & \multicolumn{3}{|l|}{ High } & \multicolumn{3}{|l|}{ Medium } & \multicolumn{3}{|l|}{ Low } \\
\hline & Observed & Expected & $S M R$ & Observed & Expected & $S M R$ & Observed & Expected & $S M R$ \\
\hline $\begin{array}{l}\text { All cancers } \\
\text { Liver cancer } \\
\text { Lung cancer } \\
\text { Brain cancer } \\
\text { Diseases of circulatory system } \\
\text { Diseases of respiratory system }\end{array}$ & $\begin{array}{r}9 \\
2 \\
2 \\
1 \\
12 \\
3\end{array}$ & $\begin{array}{r}9 \cdot 59 \\
0 \cdot 13 \\
3 \cdot 67 \\
0 \cdot 36 \\
16 \cdot 79 \\
4 \cdot 34\end{array}$ & $\begin{array}{r}93 \cdot 8 \\
1538 \cdot 5 \\
54 \cdot 5 \\
277 \cdot 8 \\
71 \cdot 5 \\
69 \cdot 1\end{array}$ & $\begin{array}{r}53 \\
1 \\
23 \\
85 \\
21\end{array}$ & $\begin{array}{r}59 \cdot 66 \\
0.77 \\
24 \cdot 42 \\
1.60 \\
110.59 \\
32 \cdot 62\end{array}$ & $\begin{array}{r}88 \cdot 8 \\
129 \cdot 9 \\
94 \cdot 2 \\
-76 \cdot 9 \\
64 \cdot 4\end{array}$ & $\begin{array}{r}53 \\
1 \\
21 \\
1 \\
83 \\
18\end{array}$ & $\begin{array}{r}57 \cdot 52 \\
0 \cdot 75 \\
23 \cdot 15 \\
1 \cdot 69 \\
106 \cdot 81 \\
30 \cdot 13\end{array}$ & $\begin{array}{r}92 \cdot 1 \\
133 \cdot 3 \\
90 \cdot 7 \\
59 \cdot 2 \\
77 \cdot 7 \\
59 \cdot 7\end{array}$ \\
\hline All deaths & 27 & $39 \cdot 85$ & $67 \cdot 8$ & 180 & $244 \cdot 18$ & $73 \cdot 7$ & 185 & $237 \cdot 16$ & 78.0 \\
\hline
\end{tabular}

Excludes one death in a man for whom an invalid measure of exposure was recorded.

Table 10 Observed and expected deaths according to whether exposure was constant or intermittent

\begin{tabular}{|c|c|c|c|c|c|c|}
\hline \multirow[t]{2}{*}{ Cause of death } & \multicolumn{3}{|l|}{ Constant } & \multicolumn{3}{|c|}{ Intermittent } \\
\hline & Observed & Expected & $S M R$ & Observed & Expected & $S M R$ \\
\hline $\begin{array}{l}\text { All cancers } \\
\text { Liver cancer } \\
\text { Lung cancer } \\
\text { Brain cancer } \\
\text { Diseases of circulatory system } \\
\text { Diseases of respiratory system }\end{array}$ & $\begin{array}{r}28 \\
2 \\
17 \\
1 \\
36 \\
11\end{array}$ & $\begin{array}{r}39 \cdot 70 \\
0 \cdot 54 \\
15 \cdot 72 \\
1 \cdot 42 \\
69 \cdot 82 \\
17 \cdot 82\end{array}$ & $\begin{array}{r}70 \cdot 5 \\
370 \cdot 4 \\
108 \cdot 1 \\
70 \cdot 4 \\
51 \cdot 6 \\
61 \cdot 7\end{array}$ & $\begin{array}{r}87 \\
2 \\
29 \\
1 \\
144 \\
31\end{array}$ & $\begin{array}{r}87 \cdot 07 \\
1 \cdot 11 \\
35 \cdot 42 \\
2 \cdot 23 \\
164 \cdot 37 \\
49 \cdot 27\end{array}$ & $\begin{array}{r}99 \cdot 9 \\
180 \cdot 2 \\
81 \cdot 9 \\
-\quad \\
87 \cdot 6 \\
62 \cdot 9\end{array}$ \\
\hline All deaths & 89 & $160 \cdot 94$ & $55 \cdot 3$ & 303 & $360 \cdot 25$ & $84 \cdot 1$ \\
\hline
\end{tabular}

Excludes one death in a man for whom an invalid measure of exposure was recorded.

Table 11 Observed and expected deaths in relation to the length of exposure and year of entry for men who were alive 15 years after they entered

\begin{tabular}{|c|c|c|c|c|c|c|c|c|c|}
\hline \multirow[t]{3}{*}{ Year of entry } & \multicolumn{9}{|c|}{ Length of exposure } \\
\hline & \multicolumn{3}{|l|}{$0-4$ years } & \multicolumn{3}{|l|}{$5-9$ years } & \multicolumn{3}{|c|}{$10-14$ years } \\
\hline & Observed & $S M R$ & Expected & Observed & $S M R$ & Expected & Observed & $S M R$ & Expected \\
\hline \multirow[t]{2}{*}{$\begin{array}{l}1940-44 \\
\text { (Deaths occurring in 1959-74) }\end{array}$} & $\underbrace{33}$ & & $32 \cdot 08$ & $\underbrace{10}$ & & $10 \cdot 30$ & 2 & & 3.48 \\
\hline & \multicolumn{3}{|c|}{103} & \multicolumn{3}{|c|}{97} & \multicolumn{3}{|c|}{$57 \cdot 5$} \\
\hline \multirow[t]{2}{*}{$\begin{array}{l}1945-49 \\
\text { (Deaths occurring in 1964-74) }\end{array}$} & $\underbrace{28}$ & & $24 \cdot 47$ & 7 & & 6.45 & $\underbrace{13}$ & & $11 \cdot 59$ \\
\hline & \multicolumn{3}{|c|}{114} & \multicolumn{3}{|c|}{109} & \multicolumn{3}{|c|}{112} \\
\hline \multirow[t]{2}{*}{$\begin{array}{l}1950-54 \\
\text { (Deaths occurring in 1969-74) }\end{array}$} & $\underbrace{18}$ & & $19 \cdot 83$ & 4 & & $3 \cdot 85$ & $\underbrace{8}$ & & $5 \cdot 87$ \\
\hline & \multicolumn{3}{|c|}{91} & \multicolumn{3}{|c|}{104} & \multicolumn{3}{|c|}{136} \\
\hline \multirow[t]{3}{*}{$\begin{array}{l}1955-59 \\
\text { (Deaths occurring in 1974) }\end{array}$} & - & & $2 \cdot 13$ & 2 & & $1 \cdot 37$ & 2 & & $1 \cdot 12$ \\
\hline & \multicolumn{3}{|c|}{ - } & \multicolumn{3}{|c|}{146} & \multicolumn{3}{|c|}{179} \\
\hline & 79 & & $78 \cdot 51$ & 23 & & $21 \cdot 97$ & 25 & & 22.06 \\
\hline Total & \multicolumn{3}{|c|}{100.6} & \multicolumn{3}{|c|}{$104 \cdot 7$} & \multicolumn{3}{|c|}{113.3} \\
\hline
\end{tabular}

tently exposed; and only $10 \%$ of those who have been constantly exposed, have been exposed to high concentrations. Thus relatively few persons have been exposed for a long time to high levels of vinyl chloride monomer and even in cases in which men have completed 20 years of service, because their service has only recently been completed, the follow-up period is too short to evaluate the carcinogenic effect of VCM.
SELECTION AND SURVIVAL IN THE INDUSTRY This population comprises men who at one time since 1940 were fit enough to obtain a job in the plastics industry. Because in general people entering employment are healthy their expected mortality rate should be lower than that observed for the population as a whole with whom comparison is made. Table 6, in which the population was subdivided into cohorts according to year of entry into the industry, 
shows that the cohorts of men who entered more recently had lower overall mortality ratios than those men who entered long ago. Figure 2 shows that similar associations are observed for cancers and for circulatory disease. Figure 3 confirms that this association between SMR and year of entry into the industry is not a function of the cohort but is related to the length of time that it has been pursued and therefore to the length of time since the individual entered the industry. Table 8 shows that it may take 20 to 30 years for this effect to disappear.

As this population comprises all men who have been identified as having worked with VCM since the industry began in Great Britain in the early 1940s, it includes men who have spent short periods in the industry as well as those who have had longer exposures. In any evaluation of the role duration of exposure plays in a model of cause and effect it is necessary to account for differences in characteristics between those subjects who stay a long time in the industry and those who leave. Most of the latter leave for reasons unrelated to health, but there are some who will leave because they are not fit enough to continue working or because they consider the job to be affecting their health. It is difficult to separate this effect, the survivor effect, from the healthy population selection effect described above. They were both clearly described by Ogle (1885) but have not been measured. The 15-year survival effect for this population has been estimated by separating those persons alive 15 years after entering the industry into those working and those not working in the industry after the 15 years. The mortality patterns after these 15 years were then compared. The SMR for men not in the industry, $108 \cdot 4$, was approximately $50 \%$ higher than for those still in the industry, $\mathbf{7 4} \cdot 0$. In a separate report we have considered at greater length the implications of these effects and the effect of the period of follow-up on the interpretation of occupational mortality studies (Fox and Collier, 1976): they are of major importance in the interpretation of these data.

\section{Other studies}

Some hypotheses concerning the effects on man of exposure to VCM have been proposed as a result of the animal experiments conducted by Maltoni and Lefemini (1975) and the epidemiological studies conducted by, for example, Tabershaw and Gaffrey (1974) and Nicholson et al. (1975). Maltoni and Lefemini (1975) have suggested that vinyl chloride monomer produced tumours in the three animal species studied: rats, mice, and hamsters. Liver angiosarcomas were observed in all three species. In addition other tumours that occurred included cerebral neuroblastomas and pulmonary adenomas. Tabershaw and Gaffrey (1974) confirmed the clinical suggestions by Creech and Johnson (1974) that there was strong epidemiological evidence that exposure to VCM caused angiosarcoma of the liver in humans. Their study also indicated an excess of cancer of the respiratory system and brain although this was not statistically significant. Nicholson et al. (1975) also confirmed that exposures to vinyl chloride monomer can cause liver cancer in humans. Although they observed three angiosarcomas of the liver and one brain cancer no deaths were due to lung cancer.

Comparisons between the findings in Great Britain and those in the USA are limited because of the differing experiences in the two countries. If we apply the same population definition as employed by Tabershaw and Gaffrey (1974), we find 331 deaths observed and $462 \cdot 29$ expected. This gives an SMR of 72 compared with one of 75 found by Tabershaw and Gaffrey (1974). Men in the high exposure group have an SMR of 59.4 compared with one of 71.7 in the medium exposure group and 73.5 in the low exposure group. An unexplained trend similar to this was noted by Tabershaw and Gaffrey (1974). We believe the trend is due to selection and survival in the industry and to the length of follow-up. Using the same population definition as Tabershaw and Gaffrey we would have found two liver cancer deaths, one of which would have been due to angiosarcoma.

Nicholson and co-workers in their study of all men in one plant with greater than five years' exposure followed-up 10 years from first employment, observed 24 deaths compared with 19.0 expected, and nine cancers compared with 3.9 expected. Included in these nine cancers were three angiosarcomas. The last two columns in Table 11 show what might be termed a high risk group in that these are people who have experienced between five and 14 years' exposure and have left the industry. They are studied here 15 years after first employment. In this group 48 deaths were observed compared with 44.03 expected. For cancer 13 were observed compared with 11.48 expected and for lung cancer six observed compared with 4.66 expected. It should be emphasised that none of the cases of liver cancer occurred in this high risk group. From Table 4 it can be deduced that a study in Great Britain similar to that conducted by Nicholson et al. (1975) would have identified one angiosarcoma and one other primary liver cancer.

\section{General assumptions and limitations}

Certain environmental factors are known to affect man's longevity. Some of these have been associated 
with particular causes of death such as cigarette smoking with lung cancer, heart disease, and bronchitis. Other associations such as those between social class and area of residence with cancers and bronchitis have not been fully explained. Epidemiology does not provide the immediate answer because the cause and effect models are complex and individual susceptibility confuses the issue. In this particular study no account has been taken of these other factors. We have assumed that the social class, smoking, and geographical distributions are similar to those for the national population with which comparison is made.

The mortality study provides a relatively crude epidemiological technique for evaluating the risk to health in the group under study. It cannot account for all the factors that may be relevant to the hypotheses that have been tested and its power is limited with respect to the detection of hazards which produce small excesses of mortality. Such studies can confirm relationships between exposures to specific chemicals and the subsequent development of uncommon tumours such as mesotheliomas, bladder cancers, and liver tumours. Unless the chemical considered is a powerful carcinogen these studies are less sensitive when studying common causes of death.

\section{Conclusions}

It is not yet possible to evaluate the overall impact of exposures to VCM on this population of workers but bearing in mind reservations discussed above two conclusions can be drawn at this stage.

The first relates to whether or not there is evidence that exposure of men to VCM in Great Britain in the manufacture of PVC caused cancer. We have observed four liver cancers, two of which were subsequently confirmed as angiosarcomas, significantly more than would have been expected. All these cancers occurred between 1970 and 1974 and similar experiences have been reported in the USA and in animal experiments. We therefore conclude that VCM is probably a carcinogen causing liver cancer in workers exposed to it. Although in this study there is little relationship with length of exposure, the angiosarcomas were associated with exposures to very high concentrations of VCM.

The second conclusion relates to whether VCM causes cancers other than those of the liver. We find no evidence to support this suggestion. Only two brain cancers were observed and there is little indication of an excess of lung cancers. The SMR for cancer as a group is consistently higher than for all deaths but because of population selection factors this is difficult to evaluate.

The effect of VCM on the mortality experience of workers exposed will only become clear after continuing this study for a further 10 years at least. Although the recently adopted hygiene standards may in future be shown to have a residual risk associated with them, men who entered the industry in recent years should be at lower risk than those who were exposed at a time when conditions were less controlled.

No study such as this could have been conducted without the assistance and co-operation of the industry and unions involved. Dr S. Gauvain was involved with the planning of this project and an early draft of this report was discussed with $\mathrm{Dr} \mathbf{M}$. Greenberg, Dr A. M. Adelstein, and Dr P. J. Baxter to all of whom we are grateful.

The EMAS Survey Control Section administered the survey, individual companies identified people who had worked in this industry, and the Office of Population Censuses and Surveys obtained and coded all death certificates.

\section{References}

Baxter, P. J. (1976). Epidemiological studies of PVC manufacturers and fabricators, and primary angiosarcoma of the liver. Proceedings of the Royal Society of Medicine, 69, 297-299.

Baxter, P. J., and Fox, A. J. (1975). Angiosarcoma of the liver as the certified cause of death 1963-73. Lancet, 1, 2728.

Block, J. B. (1974). Angiosarcoma of the liver following vinyl chloride exposure. Journal of the American Medical Association, 229, 53-54.

British Medical Journal (1974). Editorial. British Medical Journal, 1, 590-591.

Creech, J. L., and Johnson, M. N. (1974). Angiosarcoma of the liver in the manufacture of polyvinyl chloride. Journal of Occupational Medicine, 16, 150-151.

Falk, H., Creech, J. L., Heath, C. W., Johnson, M. N., and Key, M. (1974). Hepatic diseases among workers at a vinyl chloride polimerisation plant. Journal of the American Medical Association, 230, 59-63.

Fox, A. J., and Collier, P. F. (1976). Low mortality rates in industrial cohort studies due to selection for work and survival in the industry. British Journal of Preventive and Social Medicine, 30, 225-230.

Lee, F. I., and Harry, D. S. (1974). Angiosarcoma of the liver in a vinyl chloride worker. Lancet, 1, 1316-1318.

Lloyd, J. W. (1975). Angiosarcoma of the liver in vinyl chloride/polyvinyl chloride workers. Journal of Occupational Medicine, 17, 333-334.

MacMahon, H. E., Murphy, A. S., and Bates, M. I. (1947). Endothelial cell sarcoma of liver following thorotrast injections. American Journal of Pathology, 23, 585-611.

Makk, L., Creech, J. L., Whelan, J. G., and Johnson, M. N. (1974). Liver damage and angiosarcoma in vinyl chloride workers. Journal of the American Medical Association, 230, 64-68.

Maltoni, C., and Lefemini, G. (1975). Carcinogenicity bioassays'of vinyl chloride, current results. Annals of New York Academy of Sciences, 246, 195-218.

Monson, R. R., Peters, J. M., and Johnson, M. N. (1974). Proportional mortality among vinyl-chloride workers. Lancet, 2, 397-398. 
Nicholson, W. J. E., Hammond, E. C., Seidman, H., and Selikoff, I. J. (1975). Mortality experience of a cohort of vinyl chloride-polyvinyl chloride workers. Annals of New York Academy of Sciences, 246, 225-230.

Ogle, W. (1885). Letter to the Registrar General on the mortality in the registration districts of England and Wales during the ten years 1871-80. Supplement to the 145th Annual Report of the Registrar General of Births, Deaths and Marriages in England, p. xxiii.

Pearson, E. S., and Hartley, H. O. (1962). Biometrica Tables for Statisticians, vol. 1. Cambridge University Press: London.

Regelson, W., Kim, U., Ospina, J., and Holland, J. F. (1968). Haemangio-endothelial sarcoma of liver from chronic arsenic intoxication by Fowler's solution. Cancer, 21, 514-522.

Tabershaw, I. R., and Gaffrey, W. R. (1974). Mortality study of workers in the manufacture of vinyl chloride and its polymers. Journal of Occupational Medicine, 16, 509-518.

Appendix 1 Deaths in women

\begin{tabular}{|c|c|c|c|c|c|c|c|}
\hline Factory no. & Date of birth & Date of death & $\begin{array}{l}\text { Certified* cause } \\
\text { of death } \\
\text { ICD code }\end{array}$ & $\begin{array}{l}\text { Year } \\
\text { joined }\end{array}$ & $\begin{array}{l}\text { Year } \\
\text { left }\end{array}$ & $\begin{array}{l}\text { Exposure } \\
\text { levels }\end{array}$ & $\begin{array}{l}\text { Job } \\
\text { description }\end{array}$ \\
\hline 2 & 8.12 .1905 & 22.3.1965 & 5900,2901 & 1944 & 1945 & $\begin{array}{l}\text { Medium/inter- } \\
\text { mittent }\end{array}$ & Process worker \\
\hline 2 & 21.2.1899 & 4.7 .1965 & 4129 & 1942 & 1945 & $\begin{array}{l}\text { Medium/inter- } \\
\text { mittent }\end{array}$ & Process worker \\
\hline 2 & 2.9 .1893 & 28.2.1972 & 4129,4271 & 1944 & 1945 & $\begin{array}{l}\text { Medium/inter- } \\
\text { mittent }\end{array}$ & Process worker \\
\hline 2 & 10.2 .1894 & 12.10 .1968 & 9500 & 1943 & 1946 & & Process worker \\
\hline 2 & 17.10 .1879 & 22.5 .1950 & 4319 & 1940 & 1946 & & Process worker \\
\hline 2 & 12.7 .18 .97 & 8.3 .1971 & 4409,7824 & 1943 & 1945 & & Process worker \\
\hline 2 & 13.11 .1902 & 3.7 .1974 & $4109,251) 0$ & 1944 & 1945 & & Process worker \\
\hline 2 & 23.3.1921 & 5.8.1968 & $3949,4500,4530$ & 1944 & 1945 & & Process worker \\
\hline 2 & 12.7 .1894 & 11.10 .1962 & 4409,4270 & 1942 & 1945 & & Process worker \\
\hline 2 & 1.7.1894 & 5.8 .1952 & 1579 & 1942 & 1945 & & Process worker \\
\hline 2 & 19.5.1909 & 15.12 .1967 & 1519 & 1942 & 1945 & $\begin{array}{l}\text { Medium/inter- } \\
\text { mittent }\end{array}$ & Process worker \\
\hline 4 & 8.10 .1890 & 7.2 .1971 & 4540,0389 & 1943 & 1943 & Low/intermittent & $\begin{array}{l}\text { Mess room } \\
\text { attendant }\end{array}$ \\
\hline 4 & 22.8.1914 & 28.6.1949 & $4280,4109,5140$ & 1941 & 1941 & & $\begin{array}{l}\text { Worker with } \\
\text { solvents }\end{array}$ \\
\hline 4 & 3.10 .1894 & 14.11.1972 & 5810,5932 & 1941 & 1946 & & $\begin{array}{l}\text { Analytical } \\
\text { laboratory } \\
\text { attendant }\end{array}$ \\
\hline 4 & 22.1.1895 & 7.12 .1948 & $5180,7824,4280$ & 1940 & 1940 & & $\begin{array}{l}\text { Analytical } \\
\text { sampler }\end{array}$ \\
\hline 4 & 7.1 .1894 & 26.5.1966 & $5900,4271,4110$ & 1943 & 1944 & & $\begin{array}{l}\text { Worker with } \\
\text { solvents }\end{array}$ \\
\hline
\end{tabular}

*Primary cause in italics.

Appendix 2 Deaths in 1940-74 notified since analysis

\begin{tabular}{|c|c|c|c|c|c|c|c|}
\hline Factory no. & Date of birth & Date of death & $\begin{array}{l}\text { Certified }{ }^{*} \text { cause } \\
\text { of death ICD code }\end{array}$ & $\begin{array}{l}\text { Year } \\
\text { joined }\end{array}$ & $\begin{array}{l}\text { Year } \\
\text { left }\end{array}$ & $\begin{array}{l}\text { Exposure } \\
\text { levels }\end{array}$ & $\begin{array}{l}\text { Job } \\
\text { description }\end{array}$ \\
\hline 4 & 15.11 .1904 & 28.8.1963 & $2500,4850,4339$ & 1953 & 1954 & Low/intermittent & $\begin{array}{l}\text { Maintenance } \\
\text { labourer }\end{array}$ \\
\hline 4 & 21.12 .1892 & 30.8 .1955 & 9510 & 1954 & 1955 & $\begin{array}{l}\text { Medium/inter- } \\
\text { mittent }\end{array}$ & $\begin{array}{l}\text { Maintenance } \\
\text { assistant }\end{array}$ \\
\hline 4 & 13.7 .1901 & 31.3 .1962 & 4000,7920 & 1940 & 1959 & Medium/constant & Electrician \\
\hline 10 & 7.7 .1906 & 15.12 .1973 & 4109,4272 & Not known & 1971 & Low/intermittent & Security/fireman \\
\hline 10 & 18.8 .1925 & 7.7 .1972 & 4309 & Not known & 1972 & Medium/constant & $\begin{array}{l}\text { Recovery/auto } \\
\text { cleaner }\end{array}$ \\
\hline 11 & 5.3 .1907 & 13.4 .1972 & $\begin{array}{l}5151,4270,4260, \\
5170\end{array}$ & 1955 & 1956 & $\begin{array}{l}\text { Medium/inter- } \\
\text { mittent }\end{array}$ & Fitter \\
\hline 11 & 15.10 .1900 & 30.10 .1960 & $\begin{array}{l}1621,4500,4530, \\
4109\end{array}$ & 1951 & 1953 & Low/intermittent & Grinder \\
\hline 11 & 25.2 .1892 & 10.9 .1968 & 1500,4500 & 1951 & 1960 & $\begin{array}{l}\text { Medium/inter- } \\
\text { mittent }\end{array}$ & Fitter \\
\hline 11 & 9.7 .1902 & 8.8.1969 & 4360 & 1957 & 1967 & Low/intermittent & Premix operator \\
\hline
\end{tabular}

*Primary cause in italics. 